\title{
DIMENSIONS OF EMOTIONAL INTELLIGENCE AND TRANSFORMATIONAL LEADERSHIP: A CORRELATION ANALYSIS
}

\author{
John N. N. Ugoani \\ College of Management and Social Sciences, Nigeria \\ E-mail: drjohnugoani@yahoo.com
}

Christain U. Amu Federal University of Technology Owerri, Nigeria E-mail: chrisuamu@yahoo.com

Emenike O. Kalu Rhema University Aba, Nigeria E-mail: emenikekaluonwukwe@yahoo.com

Submission: $29 / 01 / 2015$

Revision: 12/02/2015

Accept: 25/02/2015

\section{ABSTRACT}

The major objective of this study was to explore the nature of relationship between emotional intelligence and transformational leadership style using Pearson correlation method. Goleman who popularized the concept of the science of emotional intelligence and brought it to its academic zenith drew on a wealth of research to argue that successful leaders need emotional intelligence, or the attributes of self-awareness, impulse control, persistence, confidence, selfmotivation empathy, social deftness, trust worthiness, adaptability, and a talent of collaboration. Data were generated through 5 - point Likert-type questionnaire based on Schutte, Self-Report questionnaire. The Pearson correlation coefficient shows a strong positive relationship between emotional intelligence and transformational leadership style. The study therefore concludes that leadership success is to a greater extent, due to emotional intelligence.

Keywords: Leadership, transformational leadership, emotional intelligence, correlation. 
INDEPENDENT JOURNAL OF MANAGEMENT \& PRODUCTION (IJM\&P)

http://www.ijmp.jor.br

v. 6 , n. 2, April - June 2015

ISSN: 2236-269X

DOI: 10.14807/ijmp.v6i2.278

\section{INTRODUCTION}

Despite the comparatively recent phenomenon of the science of emotional intelligence $(\mathrm{El})$, pioneering academic studies find significant positive relationship between emotional intelligence and transformational leadership. This suggests that effective leaders possess emotional intelligence, which is the ability to recognize and manage emotion in one's self and in others. Goleman (1995) posits that emotional intelligence is made up of several competencies including self - awareness, motivation, self-regulation, and empathy and relationship management. He proposes a mixed model of emotional intelligence in terms of performance, integrating an individual's ability and personality and applying their corresponding effects on performance in the workplace. Salovey and Mayer's (1990) conceptualization of emotional intelligence is based within the context of intelligence theory.

The pure theory of emotional intelligence integrates key ideas from the fields of intelligence and emotion. From intelligence theory comes the idea that intelligence involves the ability to carry out abstract reasoning. They propose that emotional intelligence is comprised of the ability to perceive, respond, manipulate, understand and manage emotional information without experiencing them. Bar - On (1997) put forth a model of emotional intelligence based within the context of personality theory, emphasizing the codependence of the ability aspects of the construct with personality traits and their application to personal wellbeing. (PAYNE, 1983; PETRIDES; FURNHAM, 2003, 2009; BASS, 1998, 2002; GOLEMAN, et al, 2002).

In a previous research, Mandel and Pherwani (2003) find significant relationship $(R=.50)$ between emotional intelligence and transformational leadership. According to Harms and Crede (2010) an information package by MultiHealth systems claims that emotional intelligence is synonymous with good leadership. Goleman (1998) who popularized the concept and science of emotional intelligence and brought it to its academic zenith posits that emotional intelligence is highly positively correlated with effective leadership.

Cherniss and Goleman (2001) also assert that about 90 percent of leadership success is accounted for by emotional intelligence. A foremost advocate of the relationship between emotional intelligence and transformational leadership, Bass, (2002) in a classic study finds reasonable positive correlation between the two 
INDEPENDENT JOURNAL OF MANAGEMENT \& PRODUCTION (IJM\&P)

http://www.ijmp.jor.br

v. 6, n. 2, April - June 2015

ISSN: 2236-269X

DOI: 10.14807/ijmp.v6i2.278

variables. Other studies on the relationship between emotional intelligence and transformational leadership include Antonakis, (2004), Ashkanasy and Daus (2005), Barling et al (2000).

While many studies into the relationship between emotional and transformational leadership find high levels of positive correlation others have come out with marginal or low levels of association. For example, Harms and Crede (2010) in their meta - analysis find the relationship between emotional intelligence and transformational leadership to be "quite low".

They state that "Overall, our results linking El and transformational leadership variables were not as strong or as compelling as advocates of El testing predicted" Also, in a related research, Modassir and Singh (2008) only find a "moderate relationship" between emotional intelligence and transformational leadership. Some scholars take the positive results as a proof of the predictive validity of El while some others are completely undecided (LOCKE, 2005). In a situation where the results of empirical research including a Meta-analysis are completely in a state of confusion, it becomes clear that such results are due to some errors of study. To arrive at accurate results researchers must use appropriate instruments like self - reports or performance data in assessing the relationship between emotional intelligence and transformational leadership (HARMS; CREDE, 2010).

In an attempt to address part of the confusion raised in previous studies and in particular the work of Harms and Crede (2010), this study used a simple correlation analysis to evaluate the degree of relationship between emotional intelligence and transformational leadership, This is imperative because the reason why some studies find small increases in predictive validity is in fact a methodological fallacy (SEE; BARBUTO; BURBACH, 2006; HAYASHI; EWERT, 2006; HOFFMAN; FROST 2006; LANDY, 2005; KREITNER; KINICKI, 2004; CARMELI, 2003; BENNIS, 1976).

The findings of this study will be useful to leaders and aspiring leaders of industries and even governments in Africa and other developing countries, since one of the key problems of all developing countries is bad leadership. The remainder of the paper is organized as follows. Section 2 presents the conceptual framework of emotional intelligence and transformational leadership. Section 3 embodies 
INDEPENDENT JOURNAL OF MANAGEMENT \& PRODUCTION (IJM\&P)

http://www.ijmp.jor.br

v. 6, n. 2, April - June 2015

ISSN: 2236-269X

DOI: 10.14807/ijmp.v6i2.278

methodology and data. Section 4 presents the results and discussions, and section 5 concludes the paper with policy implications.

\section{CONCEPTUAL FRAMEWORK}

\subsection{Emotional Intelligence}

Intelligence quotients (I.Q's) were developed and used during the initial part of the $20^{\text {th }}$ century as measures of intelligence. Psychologists later pioneered other modern intelligence testing movement and the validity of I.Q was soon challenged on the grounds that it did not consider situational factors such as environment or socio cultural setting while predicting achievement. Theorists began to hypothesize that perhaps cognitive intelligence as measured by I. Q tests did not encompass intelligence in its entirety, but that perhaps several types of intelligence could coincide within one person.

Gardner (1983) again raised the issue of the theory of multiple intelligences which dictated that individuals possess aptitudes in several areas. These intelligences were thought by Gardner to be as important as the type of intelligence typically measured by IQ tests. As is the case with all related constructs such as leadership and personality several schools of thought exist which aim to most accurately describe and measure the notion of emotional intelligence. Salovey and Mayer (1990) who originally used the term "emotional intelligence" define it as "A form of intelligence that involves the ability to monitor one's own and others' feelings and emotions to discriminate among them, and to use this information to guide one's thinking and actions.

At the most general level however, emotional intelligence refers to the ability to recognize and regulate emotions in ourselves and others. Goleman's (1995) Emotional Intelligence theory includes both non - intellective and intellective elements of intelligence. The non - intellective elements include: affective personal and social factors. Regardless of the differences between definitions of emotional intelligence, it is very clear that what is being referred to is distinct from standard intelligence, or $\mathrm{IQ}$.

Although the concept of emotional intelligence has different definitions it describes the ability, capacity, skill or, in the case of the trait emotional intelligence model, a self - perceived ability to identify, assess and manage emotions of one's 
INDEPENDENT JOURNAL OF MANAGEMENT \& PRODUCTION (IJM\&P)

http://www.ijmp.jor.br

v. 6, n. 2, April - June 2015

ISSN: 2236-269X

DOI: 10.14807/ijmp.v6i2.278

self, of others, and of groups. The idea of emotional intelligence lies in a handful of basic principles identified by Salovey and Mayer (1990) that they used to test how well people could identify emotions in faces, abstract designs and colors from which they wrote articles about something called "emotional intelligence".

According to Goleman (1995) emotionally intelligent people have the ability to control their emotional impulses at least more so than those who are not emotionally intelligent, they have the self - awareness to know what they are feeling, and are able to think about and express those things, they have empathy for the feelings of others and insight into how others think, they can do things like delay gratification, they are optimistic and generally positive; they understand easily the dynamics of a given group and, most importantly, where they fit inside that group.

Because of differences in definitions, different models of emotional intelligence have led to the development of various instruments for the assessment of the construct. While some of these measures may over-lap most researchers agree that they tap slightly different constructs, such as leadership. The current measure of Mayer and Salovey's model of emotional intelligence, the MayerSalovey-Caruso' Emotional Intelligence Test (MSCEIT) is based on a series of emotion-based-problem-solving items.

The model introduced by Goleman (1995) focuses on emotional intelligence as a wide array of competencies and skills that drive leadership performance. The model outlines four main emotional intelligence constructs: self-awareness, selfmanagement, social awareness and relationship management. He includes a set of emotional competencies within each construct of emotional intelligence, and suggests that emotional competencies are not innate talents, but rather learned capabilities that must be developed to achieve outstanding performance. He posits that individuals are born with a general emotional intelligence that determines their potential for learning emotional competencies.

Bar-On (1997) defines emotional intelligence as being concerned with effectively understanding one's self and others, relating well to people, and adapting to and coping with the immediate surroundings to be more successful in dealing with environmental demands. Bar-On (1997) posits that emotional intelligence develops over time and that it can be improved through training, programming, and therapy. 
INDEPENDENT JOURNAL OF MANAGEMENT \& PRODUCTION (IJM\&P)

http://www.ijmp.jor.br

v. 6, n. 2, April - June 2015

ISSN: 2236-269X

DOI: 10.14807/ijmp.v6i2.278

He hypothesizes that those individuals with higher than average emotional intelligence are in general more successful in meeting environmental demands and pressures.

He also notes that a deficiency in emotional intelligence can mean a lack of success and the existence of emotional problems. Problems in coping with one's environment are thought by Bar-On, to be especially common among those individuals lacking in emotional intelligence competencies like reality testing, problem-solving, stress tolerance; and impulse control and general mood.

In general, he considers emotional intelligence to contribute equally to a person's general intelligence which then offers an indication of one's potential to succeed in positions of importance. On the other hand Petrides (2009) Trait Emotional Intelligence Model is general and subsumes the Goleman (1995) and Bar-On (1997) models. The conceptualization of emotional intelligence as a personality trait leads to a construct that lies outside the taxonomy of human cognitive ability.

This is an important distinction in as much as it bears directly on the operationalization of the construct and the theories and hypothesizes that is formulated about it (MATTHEW et al, 2007; PETRIDE et al, 2007; BRODY, 2004; COTE; MINER 2006; ROBERT et al, 2001; VERNON et al, 2008). One of the major benefits of the conceptualization of emotional intelligence is the potential for establishing casual relationships among the various levels of a person's psyche. Boyatzis (1994) followed an often described causal link between the unconscious motive and trait level of personality to the social role and self-image level to the behavioural levels.

Need for power and leadership predicts frequency of demonstration of influence behaviours such as those evident in the competencies of the social skills cluster. According to Goleman (1995) emotional intelligence is a convenient phrase with which to focus attention on human talent and that it incorporates the complexity of a person's capability and posits that emotional intelligence is highly predictive of success. Despite differences in measurement methods all 3 major researchers on emotional intelligence agree that it provides the bedrock for competencies necessary 
INDEPENDENT JOURNAL OF MANAGEMENT \& PRODUCTION (IJM\&P)

http://www.ijmp.jor.br

v. 6, n. 2, April - June 2015

ISSN: 2236-269X

DOI: 10.14807/ijmp.v6i2.278

for superior outcomes. Goleman (1995) represents this idea by making a distinction between emotional intelligence and emotional competencies.

Emotional competence refers to the personal and social skills that lead to superior performance in work and other challenging situations like leadership. The emotional competencies are linked to and based on emotional intelligence. A certain level of emotional intelligence is necessary to learn the emotional competencies. For instance, the ability to recognize accurately what another person is feeling enables one to develop a specific competency such as influence, which provides the platform for transformational leadership (CHERNISS, 2000).

\subsection{Emotional Intelligence Models}

According to Goleman (2001) early theorists such as Gardner (1983) paved the way for the current experts in the field of emotional intelligence. Each theoretical paradigm conceptualizes emotional intelligence from one of two perspectives: ability or mixed model. Ability models regard emotional intelligence as a pure form of mental ability and thus as a pure intelligence.

In contrast, mixed models of emotional intelligence combine mental ability with personality characteristics such as optimism and well-being. Currently the only ability model of emotional intelligence is the Mayer and Salovey (1997) four branch model. Two mixed models of emotional intelligence have been postulated, each within a somewhat different conception. Bar-On (1997) has put forth a model based within the context of personality theory, emphasizing the co-dependence of the ability aspects of emotional intelligence with personality traits and their application to personal well - being.

In contrast Goleman (2001) propounded a mixed model in terms of performance, integrating an individual's abilities and personality and applying their corresponding effects on performance in the workplace. Petrides and Furnham (2007), proposed the trait emotional intelligence model which is a constellation of emotion related self - perceptions located at the lower levels of personality. Despite differences in models all the models other than none, suggest that emotional intelligence represents an ability to validly reason with emotions and to use emotions to enhance thought. Intelligence theorists posit that each of the models has a 
INDEPENDENT JOURNAL OF MANAGEMENT \& PRODUCTION (IJM\&P)

http://www.ijmp.jor.br

v. 6, n. 2, April - June 2015

ISSN: 2236-269X

DOI: 10.14807/ijmp.v6i2.278

relationship with other related constructs like leadership and personality (LOCK, 2005; ROBERT et al, 2001; SMITH et al, 2008).

\subsection{Emotional Intelligence Measures}

Due to differences in models different measures of emotional intelligence exist. The current measure of Mayer and Salovey's (1997) model is the MayerSalovey-Caruso Emotional Intelligence Test (2002). The MSCEIT is designed for individuals 17 years of age or older and aims to measure the four abilities of perception, facilitation of thought, understanding and regulation outlined by the ability model of emotional intelligence.

The MSCEIT is comprised of 141 items. The scale yields six scores $=$ an overall emotional intelligence score, expressed as an emotional intelligence quotient, or EIQ. The Bar - On Emotional Quotient Inventory $\left(E Q-{ }_{i}\right)$, is a self - report measure of emotional intelligence for individuals 16years of age and over. Developed as a measure of emotionally and socially competent behavior that provides an estimate of one's emotional and social intelligence.

The Emotional Quotient Inventory is not meant to measure personality traits or cognitive capacity but rather to measure one's ability to be successful in dealing with environmental demands and pressures 133 items are used to obtain a Total Emotional Quotient and to produce five composite scales corresponding to the 5 main components of the Bar-On (1997) Model of Emotional Intelligence such as Interpersonal EQ, Adaptability EQ, Stress management EQ, Impulse Control EQ, and General mood EQ. The items are measured on a 5-point scale ranging from 1 to 5. Total raw scores are converted into standard scores with a mean of 100 and standard deviation of 15 .

Goleman (2001) developed the Emotional Competency Inventory (ECI) as a measure of emotional intelligence based on his emotional intelligence competencies. The Emotional Competency Inventory is a multi - rater (360 degree) instrument that provides self - report, direct report, and peer ratings on seizes of behavioral indicators of emotional intelligence. It measures 20 competencies organized into the four main constructs outlined by his Mixed Model of emotional intelligence: selfawareness, social awareness, self-management, and social skills. Each respondent is asked to describe themselves or other person on a scale ranging from 1 to 7 . 
INDEPENDENT JOURNAL OF MANAGEMENT \& PRODUCTION (IJM\&P)

http://www.ijmp.jor.br

v. 6, n. 2, April - June 2015

ISSN: 2236-269X

DOI: 10.14807/ijmp.v6i2.278

Petrides, et al, (2007) developed the Trait Emotional Intelligence Questionnaire (TEIQue). The TEIQue is an open - access measure of emotional intelligence that was specifically designed to measure the construct comprehensively. The TEIQue provides an operationalization for Petrides', et al, (2007) Model that conceptualizes emotional intelligence in terms of personality. The Test encompasses 15 subscales organized under four factors. Well-being, Selfcontrol, Emotionality, and Sociability. The TEIQue scores are positively related to some of the Big Five personality traits. (BRODY 2004; PETRIDES; FURNHAM, 2009, BAR-ON,1996)

\subsection{Emotional Competence}

An emotional competence is a learned capacity based on emotional intelligence that results in outstanding performance at work. It involves emotional capacities and such critical elements as effective communication and being superb at influence, getting others to respond in a desired way. At the heart of this competence are two abilities: empathy, which involves reading the feelings of others, and social skills which allow handling those feelings artfully.

Emotional intelligence determines the potential for learning the practical skills that are based on its five domains: self - awareness, motivation, self - regulation, empathy, and managing relationships. Emotional competence shows how much of El potential that have been translated into on - the - jobs capabilities, for example, being good at serving customers is an emotional competence based on empathy; likewise, trustworthiness is a competence based on self - regulation or handling impulses and emotions well. Both customer service and trustworthiness are competencies that can make people outstanding in their work.

Emotional competencies cluster into groups each based on a common underlying emotional intelligence capacity. The underlying emotional intelligence capacity is vital if people are to successfully learn the competencies necessary to succeed in the workplace (ABRAHAM, 2004).

If they are deficient in social skills, for instance, they will be inept at persuading or inspiring others, at leading teams or catalyzing change. If they have little self - awareness, they will be oblivious to their own weakness and lack the self - confidence that comes from certainty about their strengths. A classic study by 
INDEPENDENT JOURNAL OF MANAGEMENT \& PRODUCTION (IJM\&P)

http://www.ijmp.jor.br

v. 6, n. 2, April - June 2015

ISSN: 2236-269X

DOI: 10.14807/ijmp.v6i2.278

Boyatzis (1994), suggests that in general emotional competencies play a far larger role in superior job performance than do cognitive abilities and technical expertise. (GOLEMAN, 1998; BELLAMY; BELLAMY, 2003; BESHEARS, 2004; BROWN, et al, 2006, PETRIDES; KOKKINAKI, 2007)

\subsection{Five Dimensions of Emotional Intelligence}

Goleman (1998) posits that the five dimensions of emotional intelligence are selfawareness, self-regulation, motivation, empathy, and relationship management subsumed in his four major El scales . (BARZII; SLASKI, 2003).

- Self-awareness: Self-awareness occurs when the individual knows what he is feeling in the moment, and using those preferences to guide decisionmaking, having a realistic assessment of his own abilities and a well-grounded sense of self-confidence.

- Self-regulation: This involves handling our emotions so that they facilitate rather than interfere with the task at hand; having conscientious and delaying gratification, to pursue goals; recovering well from emotional distress.

- Motivation: This dimension of emotional intelligence involves using available deepest preferences to move and guide the individual toward desired goals, to help in taking initiative and striving. To improve, and to persevere in the face of setbacks and frustration.

- Empathy: This is related to sensing what other people are feeling, being able to take their perspective, and cultivating rapport and attunement with a broad diversity of people.

- Relationship management: Relationship management manifests in handling emotions in relationships well and accurately reading social situations and networks, interacting smoothly; using these skills to persuade and lead, negotiate and settle disputes, for cooperation and teamwork. These dimensions of El are critical for transformational leadership.

\subsection{Transformational Leadership}

Leadership is an interesting area in the field of organizational behavior, one in which new studies are consistently springing up. One new important perspective of leadership is transformational leadership. Leadership is about relationships and 
INDEPENDENT JOURNAL OF MANAGEMENT \& PRODUCTION (IJM\&P)

http://www.ijmp.jor.br

v. 6, n. 2, April - June 2015

ISSN: 2236-269X

DOI: 10.14807/ijmp.v6i2.278

influence (MAXWELL, 2005). Transformational leaders inspire and excite followers to high levels of performance. Transformational leaders rely on their personal attributes instead of their official positions; they are visionary and have the capacity of converting their visions into reality (KENT, et al, 2001; ADAIR, 2003; BASS, 1990, BENNIS, 1989, BASS, 1985).

Transactional leadership, on the other hand, is about the use of reward and punishment to enhance employee performance (STERNBERG, 2003). According to Bass and Avolio, (1994), transformational leadership adds to the effects of transactional leadership, but exceptional transactional leadership cannot substitute for transformational leadership.

Research on leaders from over 200 organizations supports this idea (BONO; JUDGE, 2004). Transformational leadership is a process through which positive change or transformation is introduced to individuals and/or organizations. Bass and Avolio (1994) postulate five dimensions of transformational leadership to include idealized influence (attributed), idealized influence (behaviors), individual consideration, inspirational motivation, and intellectual stimulation.

A transformational leader is the catalyst who transforms the subordinates' motivation to commitment and their commitment into exceptional achievements. A transformational leader transforms and creates meaning for his or her subordinates, a meaning that enhances the subordinates need for identity and does this by giving meaning and strengthening the concept of the self and by boosting their individual identity (MODASSIR; SINGH, 2008). Drawing from a wealth of research, these transformational leadership dimensions are identical with the major dimensions of emotional intelligence.

\subsection{Five Dimensions of Transformational Leadership}

- Idealized influence (attributed): Involves the socialized charisma of the leader whether or not he or she is perceived as being confident and committed to high order ideas. This occurs when leaders earn the trust and respect of their followers by doing the right thing rather than ensuring that subordinates do things right. (HUMPHREYS; EINSTEIN, 2003; ANTONAKIS, et al, 2009; ANTONAKIS; HOUSE, 2002) 
- Idealized influence (behavioral): According to Harms and Crede (2010) idealized influence (behavioral) refers to charismatic actions by the leader that are based on beliefs, ideas, or values. Humphreys and Einstein (2003) believe that transformational leaders operate out of deeply held personal value systems that include qualities like justice and integrity. By expressing these personal standards, transformational leaders unite their followers and more importantly, they change their followers' goals and beliefs for the better.

- Individualized consideration. Individualized consideration is the extent to which a leader attends to the needs of his or her followers by providing socio - emotional support. It involves mentoring followers, maintaining regular contact, motivating followers for self - actualization, and providing the requisite empowerment for them. It involves moving along with followers and not moving ahead of them. This is important because leadership is dispositional and not positional. Consequently, individual consideration implicates treating the subordinates as individuals and never just as members of a work group. This transformational leadership trait is exhibited by being compassionate, empathic, and responsive to the subordinates needs by appreciating their attainments.

- Inspirational motivation: Inspiration motivation is related to the degree to which leaders inspire and appeal to followers by establishing challenging targets and expressing optimism and hope as regards target achievement. According to Conger and Kanungo (1988) inspirational motivation and charisma go hand-in-hand. They posit that transformational leaders inspire their subordinates to accomplish great feats by communicating high expectations by using symbols to focus effects and by expressing important purposes. Transformational leaders pay close attention to the individual differences among their subordinates and often act as mentors to them.

- Intellectual stimulation: Intellectual stimulation occurs when leaders engage in behaviors that make the subordinates to challenge their assumptions, think creatively, take higher risks and act in more intelligent ways. According to Shin, et al, (2003) intellectual stimulation promotes intelligence, rationality, and careful problem-solving abilities. It also involves engaging the rationality 
INDEPENDENT JOURNAL OF MANAGEMENT \& PRODUCTION (IJM\&P)

http://www.ijmp.jor.br

v. 6 , n. 2, April - June 2015

ISSN: 2236-269X

DOI: 10.14807/ijmp.v6i2.278

of the subordinates, and makes them provide answers to their problems by themselves.

\subsection{Relationship between emotional intelligence and transformational leadership}

In spite of wide disparities in the various El models and measurement methods, contemporary interest in the field of El continues to grow, and more attention is now being directed toward the relationship between emotional intelligence and transformational leadership. Cherniss and Goleman (2001) opine that emotional intelligence contributes to about 90 percent of leadership success. There is a growing number of theoretical evidence that emotional intelligence is positively correlated with transformational leadership (DAUS; ASHKANASY, 2005).

For example, El competencies like self - awareness, self - regulation, empathy, self-confidence, transparency, and optimism are critical for transformational leadership (GOLEMAN, et al, 2002). Emotional management promotes positive effect and confidence in followers, leaders who are self - aware possess a greater than average sense of purpose and meaning and equally people skilled in emotional intelligence frequently put the needs of others ahead of their own individual needs. According to George (2000) emotional appeal is needed by transformational leaders for inspirational motivation of their subordinates.

According to Brown et al (2006) adherence to professional or moral standard of behavior are common aspects of both emotional intelligence and transformational leadership. Barling, et al (2000) observe that emotional intelligence is associated with three dimensions of transformational leadership such as idealized influence, inspirational motivation, and individualized consideration.

Gardner and Stough (2002) state that the ability to manage emotions in relationships allows the emotionally intelligent leader to understand followers needs and to react accordingly. Social intelligence is imperative in leadership positions. Stenberg (2003) defines social intelligence as the ability to perceive one's own and others' internal state, motives and behaviors, and to act towards them optimally on the basis of that information.

Researchers in the area of leadership state that effective transformational leaders must possess social and emotional intelligence. These elements are 
INDEPENDENT JOURNAL OF MANAGEMENT \& PRODUCTION (IJM\&P)

http://www.ijmp.jor.br

v. 6, n. 2, April - June 2015

ISSN: 2236-269X

DOI: 10.14807/ijmp.v6i2.278

considered critical to inspire followers and to build strong relationships. Research comparing emotional intelligent and transformational leadership consistently finds positive correlations between the two constructs.

In a study examining transformational leadership and emotional intelligence in 32 individuals in management positions, Mandell and Pherwani (2003) find that the level of emotional intelligence as measured by the Bar - On (1997) Emotional Quotient Inventory $(E Q-i)$ significantly relate to transformational leadership style $(R$ $=.50)$ Also, the MSCEIT (2002) reports a positive correlation between EI and transformational leadership.

\subsection{Hypotheses}

Using emotional intelligence as the index of positive transformational leadership behaviors, the present study hypothesizes thus:

$\mathrm{H}_{\mathrm{O}}$ : Emotional intelligence has no correlation with transformational leadership.

$\mathrm{H}_{\mathrm{i}}$ : $\quad$ Emotional intelligence has correlation with transformational leadership.

\section{METHODOLOGY AND DATA}

\subsection{Research design}

The research adopts survey design. The survey design describes a technique of data collection in which questionnaire was used to collect data about an identified population (BURNS; GROVE, 1993). The design can also be used to assess interrelationships. According to Shaughnessy and Zechmeister (1997), this design is ideal to address the descriptive functions with correlational research.

\subsubsection{Participants}

The sample comprised of a dyad of 47 managers and subordinates, ranging in age from 18 to 70 years, and an average work experience of 15.5 years, holding current positions for 6.5 years on the average. The participants totaling 94 (male $70 \%$ ) and (Female 30\%) engaged in different industries and occupations were obtained from the general population in Aba, Abia State, Nigeria. The author personally administered the questionnaire on the participants in the various organizations. All the questionnaire copies distributed were retrieved representing 100 percent response rate. 


\subsubsection{Instrument}

Data were collected using the composite El type-scale developed by Schutte, et al, (1998). The scale is comprised of 33, 5 - Point Likert - type scale, with numeric values ranging from 1 strongly disagreed to 5 strongly agreed. Previous investigations find the total scores on the Schutte Self - Report Emotional Intelligence (SSREI) to be acceptably internally consistent at about .90

\subsubsection{Procedure}

Total score was derived by summing up the item responses. Validation included comparison with theoretically related constructs like personality, alexithymia, and emotion. Data were coded using strict coding procedures and coding sheets to ensure a high level of accuracy and rating agreement (JONKER; VOSLOO, 2010; HARMS; CREDE, 2010). The resultant scores corresponding with the five dimensions of emotional intelligence and five dimensions of transformational leadership were then used for simple correlation analysis. Contemporary emotional intelligence researchers such as Modassir and Singh (2008) and Harms and Crede (2010) state that emotional intelligence factors of self - awareness, self confidence, emotional management, empathy and transparency are positively correlated with transformational leadership style. The data were presented in Table 1

\subsection{Data Analysis}

To investigate the relationship between emotional intelligence and transformational leadership, this study employs the descriptive and correlation analyses. Descriptive analysis involves computing of mean, standard deviation, skewness, kurtosis, and Jarque-Bera statistic for the variables. Correlation analysis, on the other hand, describes the degree of relationship between two variables, and ranges from -1.00 to 1 , with -1.00 and 1.00 representing perfect negative and positive relationships respectively and 0 representing a lack of relationship between the variables. The descriptive analysis and correlation coefficient are presented in Tables 2 and 3. 


\section{PRESENTATION OF DATA AND DISCUSSION OF RESULTS}

\subsection{Presentation of Data}

Table 1: Emotional Intelligence (EI) factor score and Transformational Leadership $(\mathrm{TL})$

\begin{tabular}{lll}
\hline Variables of interest & El factor score $(\mathbf{X})$ & TL $(\mathrm{Y})$ \\
\hline Self - awareness & 2.18580 & 9.5 \\
Self - confidence & 0.10519 & 8.2 \\
Emotional management & -0.60102 & 6.0 \\
Empathy & -0.87804 & 4.4 \\
Transparency & -0.62185 & 4.9 \\
\hline
\end{tabular}

Source: Authors' computation

\subsection{Descriptive Analysis}

Table 2: Descriptive statistics of El and TL

\begin{tabular}{lrr}
\hline & El Factor Score & \multicolumn{1}{c}{ Leadership } \\
\hline Mean & 0.038016 & 6.6 \\
Standard Error & 0.561268082 & 0.976217189 \\
Standard Deviation & 1.255033585 & 2.182887995 \\
Sample Variance & 1.5751093 & 4.765 \\
Kurtosis & 3.255738318 & -1.988773509 \\
Skewness & 1.810779097 & 0.509063087 \\
\hline
\end{tabular}

\subsection{Correlation Analysis}

The correlation analysis was used to examine the degree of relationship between emotional intelligence and transformational leadership. Notice the very high and positive correlation between emotional intelligence and transformational leadership presented in Table 3. This suggests that emotional intelligence has strong positive relationship with transformational leadership. This result supports numerous prior research results, that emotional intelligence account for about 90 percent of leadership effectiveness (GOLEMAN et al, 2002; CHERNISS; GOLEMAN, 2001; MANDELL; PHERWANI, 2003; BASS; AVOLIO, 1994; BENNIS, 1989).

Bennis (1989), for instance, finds that emotional intelligence is more important for success than any other asset, including IQ, or technical expertise. Leaders must develop healthy relationships and manage conflict while achieving productive goals. To accomplish this mandate, leaders need emotional intelligent skills to build, 
maintain and strengthen partnerships within and outside their organizations. Goleman (1995) insists that the effective leaders have a knack for articulating a mission or a goal and knowing how to bring everyone on board to get it accomplished.

Table 3: Correlation Coefficient and t-Test: Paired Two Sample for Means Results

\begin{tabular}{lrr}
\hline & El Factor Score & Leadership \\
\hline Observations & 5 & 5 \\
Pearson Correlation & 0.899454036 \\
Hypothesized Mean Difference & 4 \\
Df & -12.34894243 \\
t Stat & 0.000123552 \\
$\mathrm{P}(\mathrm{T}<=\mathrm{t})$ one-tail & 2.131846782 \\
t Critical one-tail & 0.000247105 \\
$\mathrm{P}(\mathrm{T}<=\mathrm{t})$ two-tail & 2.776445105 \\
t Critical two-tail & \\
\hline
\end{tabular}

\section{CONCLUSIONS}

This study adopted a simple correlational approach, distinct and different from some other methods used by prior researchers, to examine the relationship between emotional intelligence and transformational leadership. The result obtained from Pearson correlation show evidence of strong positive relationship between emotional intelligence and transformational leadership.

The findings of this study show that leaders must embrace the attributes of emotional intelligence to achieve desired results. The result demonstrates the significant impact emotional intelligence of the leader can have on the subordinates. Self-confidence for example, allows the leader to take decisions without much procrastination, to defy the crowd and move along with the subordinates. Transparency is a fundamental requirement of transformational leadership that is embedded in emotional intelligence. Emotional management helps leaders in properly managing themselves and subordinates with the sole aim of achieving organizational excellence.

We therefore conclude that leadership success is to a greater extent, due to emotional intelligence. 


\section{REFERENCES}

ABRAHAM, R. (2004), Emotional Competence as antecedent to performance. A contingency framework; Genetic, Social, and General Psychology Monographs, v. 130 , n. 2 , p. $117-143$.

ADAIR, J. (2003) How to grow leaders: The seven principles of effective leadership development. Kogan Page, London.

ANTONAKIS, J.; ASHKANASY, N.; DASHBOROUGH, M, (2009) Does leadership need emotional intelligence? The leadership Quarterly, n. 20, v. 247-261.

ANTONAKIS, J.; HOUSE, R. (2002). The full - range leadership theory: The way forward Transformational and Charismatic Leadership, n. 2, p. 3-33.

ANTONAKIS J. (2004) On why "emotional intelligence" will not predict leadership effectiveness beyond IQ or the "Big Five". An extension and rejoinder.

Organizational Analysis, n. 12, p. 171-182.

ASHKANASY, N.; DAUS, C. (2005) Rumors of the death of emotional intelligence in organizational behavior are greatly exaggerated. Journal of Organizational

Behavior, n. 26, p. 441-452.

AVOLIO, B. (1994), The natural: Some antecedents to transformational leadership. International Journal of Public Administration, n. 17, p. 1559-1581.

AVOLIO, B. (1999) Full leadership development: Building the vital forces in organizations. Thousand Oaks, CA, Sage.

BARLING, J.; SLATER, F.; KELLOWAY, E. K. (2000) Transformational Leadership and Emotional Intelligence: An exploratory study. Leadership and Organization Development Journal, n. 21, p. 157-161.

BARBUTO, J. E.; BURBACH, M. E. (2006). The emotional intelligence of transformational leaders: A field study of elected officials. The Journal of Social Psychology, n. 146, p. 51-64.

BARDZILL, P.; SLASKI, M. (2003). Emotional Intelligence: Fundamental competencies for enhanced service provision, Managing Service Quality, v. 13, n. 2, p. 97-104.

BAR-ON, R. (1996). The Emotional Quotient Inventory $(E Q-i)$ : A test of emotional intelligence. Toronto: Multi - Health Systems.

BAR - ON, R. (1997) Bar-On Emotional Quotient Inventory. Toronto, Multi Health Systems.

BAR - ON, R, (2006). The Bar - On Model of Emotional - Social Intelligence (ESI) Psicothema, 18, supl; p. 13-25.

BASS, B. M. (1985) Leadership and performance beyond expectation. New York: Free Press.

BASS, B. M. (1990). Bass and Stog-dill's Handbook of Leadership. Theory, Research and Managerial Applications. New York, The Free Press.

BASS, B. M. (1998) Two decades of research and development in transformational leadership. European Journal of Work and Organizational Psychology. n. 8, p. 932. 
BASS, B. M. (2002) Cognitive, Social and Emotional intelligence of transformational leaders. Multiple Intelligences and Leadership, p. 105-118.

BASS, B.; AVOLIO, B. (1994). Full range leadership development: Manual for the multi factor leadership questionnaire. Palo Alto, CA: Mind Garden.

BELLAMY, A. R.; BELLAMY, A. R. (2003) Emotional intelligence and transformational leadership: Recursive leadership process within the context of employee work attitudes. Paper presented at the Midwest Academy of Management.

BENNIS, W. (1976) Leadership: A Beleaguered Specie? Organizational Dynamics, 5.

BENNIS, W. (1989) Why Leaders can't Lead: The Unconscious Conspiracy Continues. San Francisco. Jossey - Bass Publishers.

BESHEARS, R. S. (2004). The ability of emotional intelligence to predict transformational leadership when personality, affect, and cognitive ability are controlled Unpublished Dissertation. Wayne State University, Detroit. MI.

BONO, J.; JUDGE, T. (2004). Personality and transformational and transactional leadership. A meta - analysis. Journal of Applied Psychology, n. 89, p. 901-910.

BOYATZIS, R. E. (1994) Stimulating self - directed learning through the management assessment and development course. Journal of Management Education, v. 18, n. 3, p. 304-323.

BOYATZIS, R. E.; GOLEMAN, D.; HAY/MCBER. (1999) Emotional Competence Inventory. Boston, Hay Group.

BROWN, F. W.; BRYANT, S. E.; REILLY, M. D. (2006) Does emotional intelligence as measured by the $E Q-i$ - influence transformational leadership and/or desirable outcomes?. Leadership and Organization Development Journal, n. 27, p. 330351.

BROWN, F. W.; MOSHAVI, D. (2005) Transformational leadership and Emotional Intelligence: A potential pathway for an increased understanding of interpersonal influence. Journal of Organizational Behavior. n. 76, p. 867-871.

BRODY, N. (2004). What cognitive intelligence is and what emotional intelligence is notl. Psychological Inquiry, n. 15, p. 234-238.

BURNS, N.; GROVE, S. K. (2005) The practice of nursing research, conduct, critique, and utilization, $2^{\text {nd }}$ edition. Philadelphia, Saunders.

CARUSO, D. R.; MAYOR, J. D.; SALOVEY, P. (2002). Relation of an ability measure of emotional intelligence to personality. Journal of Personality Assessment. v. 79, n. 2, p. 306-320.

CARMELI, A. (2003) The relationship between emotional intelligence, work attitudes, behaviour and outcomes. An examination among Senior Managers. Journal of Managerial Psychology, v. 18, n. 8, p. 788-813.

CHERNISS, C. (2000) Emotional Intelligence: What it is and Why it Matters. The Consortium for Research on Emotional Intelligence in Organizations. Paper Presented at the Annual Meeting of the Society for Industrial and Organizational Psychology, New Orleans, L. A, April 15, 2000. 
CHERNISS, C.; GOLEMAN, D, (2001) The Emotionally Intelligent Workplace, San Francisco, Jossey - Bass.

CONGER, J. A.; KANUNGO, R. (1988) Charismatic Leadership: The elusive factor in Organizational Effectiveness. San Francisco. Jossey-Bass.

COTE, G.; MINERS, C. T. H. (2006) Emotional Intelligence, cognitive intelligence and job performance. Administrative Science Quarterly, v. 51, n. 1, p. 1-28.

DAUS, C.; ASKANASY, N. (2005) The case for the ability based model of emotional intelligence in organizational behaviour. Journal of Organizational Behaviour. $n$. 26, p. 453-460.

GARDNER, H. (1983), Frames of Mind: A Theory of Multiple Intelligences. New York, Basic Books.

GARDNER, L.; STOUGH, C. (2002) Examining the relationship between leadership and emotional intelligence in Senior level managers. Leadership \& Organizational Development Journal, v. 23, n. 2, p. 68-78.

GEORGE, J. M. (2000) Emotions and Leadership: The role of emotional intelligence. Human Relations, v. 53, n. 8, p. 1027-1054.

GOLEMAN, D. (1995). Emotional intelligence. Why It Can Matter More Than IQ. New York, Bantam books.

GOLEMAN, D. $\left(1998^{\mathrm{a}}\right)$ Working with Emotional Intelligence. New York, Bantam Books.

GOLEMAN, D. $\left(1998^{\mathrm{b}}\right)$. What makes a good leader? Harvard Business Review, November/December, 93 - 102.

GOLEMAN, D. (2001) An EI - Based Theory of Performance. In Cherniss, C, \& Goleman, D, (Eds). The Emotionally Intelligent Workplace. p:27 - 45. San Francisco, Jossey - Bass.

GOLEMAN, D. (2006) Emotional Intelligence: Why It Can Matter More Than IQ. $10^{\text {th }}$ Anniversary edition, New York, Bantam Books.

GOLEMAN, D.; BOYATZIS, R. S.; MEKEE A. (2002) Primal Leadership: Realizing the Power of Emotional Intelligence, Boston, Harvard Business School Press, p. 39.

HARMS, P. D.; CREDE, M. (2010) Emotional Intelligence and Transformational and Transactional leadership: A meta-analysis. Journal of Leadership \& Organizational Studies, v. 17, n. 1, p: 5-17.

HAYASHI, A.; EWERT A. (2006) Outdoor leaders' emotional intelligence and transformational leadership. Journal of Experimental Education, n. 28, p. 222-242.

HOFFMAN, B. J.; FROST, B. C. (2006) Multiple intelligences of transformational leaders: An empirical investigation. International Journal of Man power, n. 27, p. 37-51.

JONKER, C. S.; VOSLOO, C. (2010) The Psychometric Properties of the Schutte Emotional Intelligence Scale. SA Journal of Industrial Psychology. v. 34, n. 2, p. 21-20. 
KONTSOYIANNIS, A. (2003) Theory of Econometrics, $2^{\text {nd }}$ Edition, New York, Palgrave.

KREITNER, R.; KINICKI, A. (2004) Organizational Behaviour. $6^{\text {th }}$ Edition. New York, McGraw-Hill.

LANDY, F. (2005) Some historical and scientific issues related to research on emotional intelligence. Journal of Organizational Behaviour, n. 26, p. 411-424.

LOCKE, E. (2005) Why emotional intelligence is an invalid concept. Journal of Organizational Behavior, n. 26, p. 425-431.

HUMPHREYS, J.; EINSTEIN, W. (2005) Nothing new Under The Sun:

Transformational Leadership from Historical Perspective. Management Decision, v. 41, n. 1, p. 85-95.

KENT, T.; CROTTS J.; AZIZ, A. (2001) Four factors of transformational leadership behavior Leadership \& Organization Development. Journal, v. 22, n. 5, p. 221-229

MANDELL, B.; PHEVWANI, S. (2003) Relationship between Emotional Intelligence and Transformational Leadership Style: A gender comparison. Journal of Business and Psychology. v. 17, n. 3, p. 387-404.

MAXWELL, J. C. (2005) The $360^{\circ}$ Leader. Tennessee, Thomas Nelson, Inc. MATTHEWS, G.; ZEIDNER, M.; ROBERTS, R. (2002) Emotional Intelligence. Science and Myth. Cambridge, MA: MIT Press.

MAYER, J. D.; SALOVEY, P. (1997) What is Emotional Intelligence? Emotional development and emotional intelligence: Educational implications. New York, Basic Books.

MAYER, J. D.; SALOVEY, P.; CARUSO, D. R. (2002) The Mayer, Salovey, Caruso, Emotional Intelligence Test (MSCEIT): Users, Manual. Toronto: Multi - Health Systems.

MODASSIR, A.; SINGH, T. (2008) Relationship of emotional intelligence with transformational leadership and organizational citizenship behaviour. International Journal of Leadership Studies. V. 4, n. 1, p: 3-21.

NWORUH, G. E. (2004) Basic Research Methodology for Researchers and Trainers in Management Sciences. $2^{\text {nd }}$ Edition, Owerri, Ambix Printers Nigeria.

PAYNE W. L. (1983) A study of Emotion. Developing emotional intelligence.

Dissertation Abstracts International, n. 47, p:23A.

PETRIDES, K., V.; FURNHAM, A. (2001) Trait emotional intelligence: Psychometric investigation with reference to established taxonomies. European Journal of Personality, n. 15, p. 425-448.

PETRIDES, K., V.; FURNHAM, A. (2003) Trait emotional intelligence: Behavioural validation in two studies of Emotion, cognition, and reactivity to mood induction.

European Journal of Personality, n. 17, p. 39-75.

PETRIDES, K., V.; FURNHAM, A. (2009) On the Dimensional Structure of Emotional Intelligence. Personality and Individual Differences. n. 29, p. 313-320.

PETRIDES, K., V.; FURNHAM, A. (2007) The location of trait emotional intelligence in personality factor space. British Journal of Psychology, n. 98, p. 273-289. 
PICCOLO, R. E.; COLGNITT, R. J. (2008) Transformational leadership and job behaviours: The mediating role of core job characteristics, Academy of Management Journal, v. 49, n. 2, p. 327-340.

ROBERTS, R. D. (2001) Does emotional intelligence meet traditional standards for intelligence? Some new data and conclusions. Emotion, n. 1, p. 196-231.

SCHUTTE, N. S.; MALOUFF, J. M.; HALL, I. E.; HAGGERTY, D. J.; COOPER, J. T.; GOLDEN, C.; DORNHEIM, L. (1998) Development and validation of a measure of emotional intelligence. Personality and Individual Differences, v. 25, n. 2, p. 167177.

SALOVEY, P.; MAYER, J. D. (1990) Emotional intelligence. Imaginations, Cognition, and Personality, v. 9, n. 3, p. 185-211.

SHAUGHNESSY, J. J.; ZECHMEISTER, E. B, (1997) Research methods in Psychology. $4^{\text {th }}$ edition. New York, McGraw - Hill.

SHIN, S. J.; ZHOU, J, (2003) Transformational leadership, conservation, and creativity. Evidence from Korea. Academy of Management Journal, v. 46, n. 6, p. 703-714.

SMITH, L.; CIARROCHI, J.; HEAVEN, P. C. L, (2008) The stability and change of trait emotional intelligence, conflict communication patterns and relationship satisfaction: A one-year longitudinal study. Personality and Individual Differences, n. 45, p. $738-743$.

TURNER, N.; BARLING, J.; EPITROPSKI, O.; BUTCHER, V.; MILNER, C. (2002) Transformational leadership and moral reasoning. Journal of Applied psychology, n. 87, p. 304-311.

VERNON, P. A.; PETRIDES, K, V.; BRATKO, D.; SCHERMER, J. A. (2008) A behavioural genetic study of trait emotional intelligence. Emotion, n. 8, p. 635-642. ZEIDNER, M.; MATTHEWS, G.; ROBERTS, R. D. (2004) Emotional intelligence in the workplace: A critical review. Applied Psychology, v. 53, n. 3, p. 371-399. 